\title{
23. Chronic or Acute Land Deformations Occurring along the Median Line.
}

\author{
By Akitune ImAmurA, M. I. A. \\ (Comm. Sept. 12, 1947.)
}

As pointed out by Dr. K. Watanabe ${ }^{1)}$, land stretching along the so-called Median Line, the tectonic line traversing Kyūsyū, Sikoku, and Honsy $\bar{u}$, associated here and there with a zone of serpentine intrusion, is generally under the sway of considerable telluric forces exerted there from various sides like hydrostatic pressure, so that civil works, particularly railway tunnels, must be necessarily so constructed as they can resist the said forces. It will thus naturally be expected that, in cases when level line passes across the said tectonic line, conspicuous change in land-level would occur sometimes in a chronic manner, or otherwise in an acute manner, in which case large earthquake shall take place as an accompaniment. The matter has been taken in hand as the subject of my study; places in question have been closely examined with the result that there occurred such changes with almost no exception. In the following lines are given their detailed accounts per each place, beginning from the western extremity in Kyūsyū and ending on the north-east in the vicinity of Itoigawa in Etigo Province.

1) Near Kumamoto. That section of level line linking Kumamoto on the north with Yatusiro on the south crosses the Median Line at a point near Udo. where occurred an $\mathrm{N}$-shaped discontinuity in landlevel with a throw of as much as $5.9 \mathrm{~cm}$ as undergone during the period of 45 years ending in $1936^{2}$. Another discontinuity with a throw of $6.4 \mathrm{~cm}$ occurred about $8 \mathrm{~km}$ to the south of Kumamoto. The latter might be connected in some way with the violent Kumamoto earthquake of 1889 , seeing that the said discontinuity took place within the area worst shaken by the earthquake $e^{33}$.

2) Near Ooita. Hear the Median Line runs from north-east to south-west across the city of Ooita or thereabout, while that section of level line linking Sakanoiti with Kokura runs along the south coast of the same bay traversing the tectonic line in the vicinity of Ooita or Beppu. Changes in land-level undergone during the period of either 40 or 44 years down to 1936 was rather insignificant; $\mathrm{N}$-shaped discontinuities with throws of 3.0 and $2.6 \mathrm{~cm}$ having occurred respectively on the east and west of the city of Ooita ${ }^{4)}$. The acute changes in land-level of a tremendous scale. however, were experienced in the district in 1596 and again in the next year, possibly with chronic changes during the ensuing years as well. The fact is that, with the great 1596 earthquake, Ury $\bar{u}-z i m a$, an island $4.0 \times 2.3 \mathrm{sq} . \mathrm{km}$ in size,

1) K. Watanabe: Tigaku-zassi, 575 (1937), 23.

2) Bull. Earthq. Res. Inst., 15 (1937) 569.

3) A. Imamura: Rep. Earthq. Inv. Comm., 92 (1920), 1.

4) Bull. Earthq. Res. Inst., 15 (1937), 569. 
sank down under the sea, while Hisamitu-zima, which was situated on the west of the former, disappeared next year, a submarine trench,

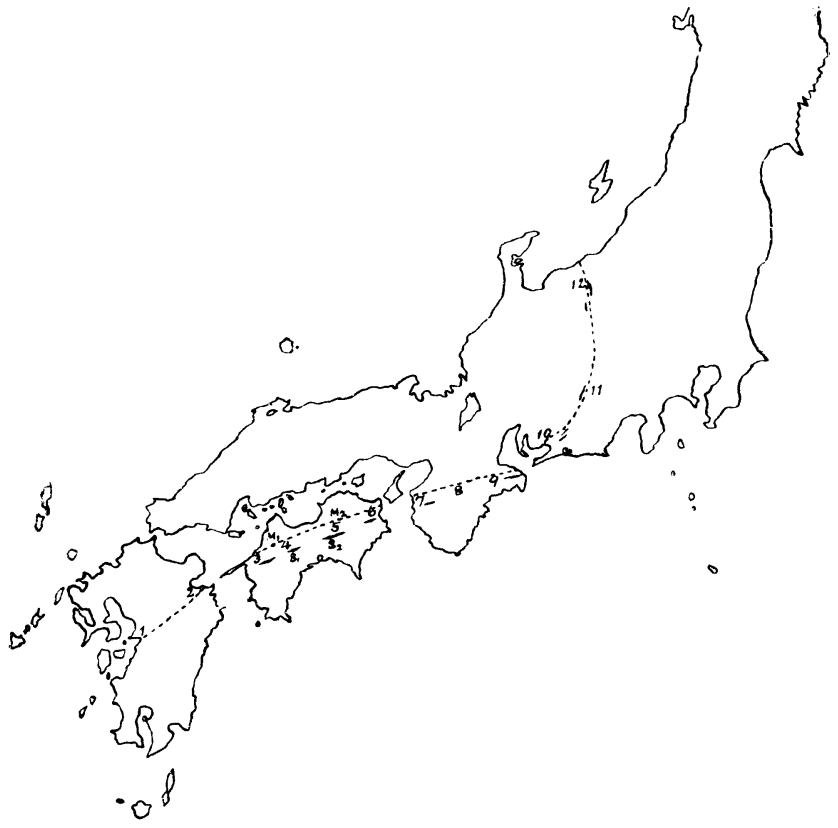

Fig. 1.

60-70 metres deep at present, occupying the former sites of the lost islands and a narrow area extending further eastwards ${ }^{1 \text {. }}$.

Again, there occurred another destructive earthquake on December 26,1854 , that is to say, 40 hours later than that great regional Nankaido earthquake on Dcember 24, the town of Turusaki, about $10 \mathrm{~km}$ east of Ooita, having been worst shaken as was the case with the 1596 earthquake. The epicentre might have been situated on the Median Line rather eastwards than in the case of the 1596 earthquake.

3) West Sikoku. In Sikoku, the Median Line and the serpentine zone run from west to east almost parallel to each other with a distance of about $25 \mathrm{~km}$ in average. They are crossed by lines of level at four places, one to be examined here being the westernmost.

The section of level line linking Matuyama on the north-east with Yahatahama on the south-west crosses the Median Line near Utikomati (B.-M. 4549-52), or rather at the place known as Yoruhiru Tunnel. Here considerable changes in land-level happened; while N-shaped discontinuities occurred respectively with throws of as much as 12.8 and $1.3 \mathrm{~cm}$ in the periods of 41 years ending in 1937 and the ensuing 4 years, land to the north tilted northwards during the 41 earlier years, whereas it tilted southward during the ensuing 4 years.".

Violent earehquakes occurred in the district in $1685,1688,1694$,

1) A. Imamura: Proc. (in Japanese), 4 (1947), 185.

2) A. Imamura and N. Miyabe: Proc. 18 (1942), 395. 
$1749,1850,1854$, and 1857, the last having shaken the district concerned particularly badly ${ }^{1}$.

4) West-Central Sikoku. The line of levels linking Matsuyama on the north with Sagawa-mati in Tosa Province on the south crosses the Median Line and the serpentine zone respectively at $M_{1}$ and $S_{1}$ (Fig. 1), changes in land-level undergone during the 42 years ending in 1939 having been as follows ${ }^{2}$

At $M_{1}$ (4 bench-marks extent north of Kuma-mati) : an $N$-shaped discontinuity with a throw of $6.3 \mathrm{~cm}$.

At $S_{1}$ (9 bench-marks extent south-east of Kuma-mati): an Nshaped discontinuity with a throw of $13.0 \mathrm{~cm}$.

5) East-Central Sikoku. The line of levels liking Tatukawamura near Zentūzi on the north with Kōti via Ikeda on the south crosses the Median Line and the serpentine zone respectively at $M_{2}$ and $S_{2}$ (Fig. 1), changes in land-level undergone during the period as in No. 4 having been as follows ${ }^{3 \text {. }}$.

At $M_{2}$ (in Ikeda-mati): an $\mathrm{N}$-shaped discontinuity with a throw of $3.8 \mathrm{~cm}$.

At $S_{2}$ (in Nisi-Toyonaga-mura): an $\mathrm{N}$-shaped discontinuity with a throw of as much as $31.0 \mathrm{~cm}$.

6) East Sikoku. The line of levels running the eastern coast of Sikoku crosses the Median Line in the Tokusima depression where was experienced a depression of $4-5 \mathrm{~cm}$ in the period of 41 years ending in $1937^{4}$.

No large earthquakes are likely to have originated in historic times in or near the area concerned with No. 5 or No. 6.

7) West Kii. In the western part of Kii peninsula, a line of precise levels runs along the coast, crossing the Median Line in or near the city of Wakayama, while another line is laid down along the River Kinokawa such that the level line runs almost along the tectonic line. There have been occurring characteristic changes in landlevel at two places; one near Wakayama with a throw of $5.4 \mathrm{~cm}$ in the period of 46 years ending in 1932, and the other near Kii-Miidera, where an upwarp of $7.4 \mathrm{~cm}$ occurred in the period of 34 years ending in $1928^{5)}$. Associated with the latter took place earthquake swarms in Nagusa County; they began in 1920 and attained their maximum frequency in $1923^{6}$

8) The central part of Kii peninsula. The section of level line linking Godyō on the north with Ukegawa on the south is likely to cross the Median Line at a point close to its northern terminus, where a change in land-level as undergone in the period of 32 years ending in 1931 occurred as a discontinuity with a throw of $9.6 \mathrm{~cm}^{7}$.

1) A. Imamura: Proc.

2) Military Land Survey: Results of the Revision of Level Lines in the 1938 fiscal year.

3) Bull. Earthq. Res. Inst., 17 (1939), 826.

4) Loc. cit., 16 (1938), 484.

5) A. Imamura: Proc., 9 (1933) 39.

6) A. Imamura, T. Kodaira, and H. Imamura : Bull. Earthq. Res. Inst., 10 (1932), 636.

7) A. Imamura: Proc., 9 (1933), 39. 
As an example of large earthquakes likely to be closely connected with the present section of the weak line may be mentioned the Koyasan earthquake of 1038. The great Yamato-Kii earthquake of 734 might be another one belonging to the same system.

9) The eastern part of Kii peninsula. Here the line of precise levels linking Matusaka on the north with Nagasima on the south did not show any remarkable change in land-level at the place where it crosses the Median Line, whereas at the meeting point with the line of serpentine intrusion, a vertical change of as much as $8.0 \mathrm{~cm}$ came out as one undergone during the period of 36 years ending in 1931'.

10) Mikawa Province. The section of level line linking Toyokawa with Okazaki in the Tōkaido highway crosses the Median Line in Nagasawa-mura, where a conspicuous change in land-level occurred during the period of 31 years ending in 1931 as an $\mathrm{N}$-shaped discontinuity with a throw of as much as $19.9 \mathrm{~cm}$, the westernside undergoing an upwarp ${ }^{2}$. Eventually the great Atumi Bay earthquake of January 13, 1945, took place in the district associated with the land deformation of the same mode, seismic fault then occurred having been traceable further south-wards in the bay as a dislocation upheaving the western side relatively against the other as much as one metre. The said discontinuity in land- level, together with land deformations, which were noticed by Dr. N. Miyabe ${ }^{33}$, as to have been going on at the north coast of Atumi Bay, would suggest that both were the phenomena closely connected with the 1945 earthquake.

11) The middle course of the River Tenryü-gawa. That section of level line linking Kakegawa with Suwa in Sinano, runs almost along the course of the Tenry $\bar{u}$-gawa, crossing the Median Line at Toyama-dani or near it, where very conspicuous changes in land-level occurred during the period of 32 years ending in 1934 as a fold-like deformation with an uplift of as much as $55.4 \mathrm{~cm}$ on the east and a depression of $27.6 \mathrm{~cm}$ on the west ${ }^{4}$. The destructive Toyama-dani earthquake of August 22, 1718, might have some connection with the present land deformation, the earthquake having been destructive not only in Toyama-dani but also in the area stretching south-westwards along the Median Line as far as Sakabe, Sata, and Otani for a distance of about $20 \mathrm{~km}$.

There occurred besides another fold-like deformation on the south of the former at the point where the Tenryu-gawa changes its general easterly course once again into the southerly, with a range of upheaval and depression as much as $23.8 \mathrm{~cm}$.

The Tōtōmi earthquake of 715 , in which case the Tenrȳ̄-gawa was temporarily blocked by landslides and caused an inundation of a tremendous scale, might been connected with the above-mentioned

1) Bull. Earthq. Res. Inst., 10 (1932), 490.

2) Ibid. As to the conspicuous $\mathrm{N}$-shaped discontinuity in question the Bulletin adds a few words that its cause is unknown.

3) He worked out the result from mareographic data obtained at Senma, Nisiura, and Maesiba in the period from 1931 to 1944.

4) Bull. Earthq. Res. Inst., 12 (1934), 639. 
land deformation, while the Mikawa earthquake, which took place on the next day, may be assumed as to have originated in an area

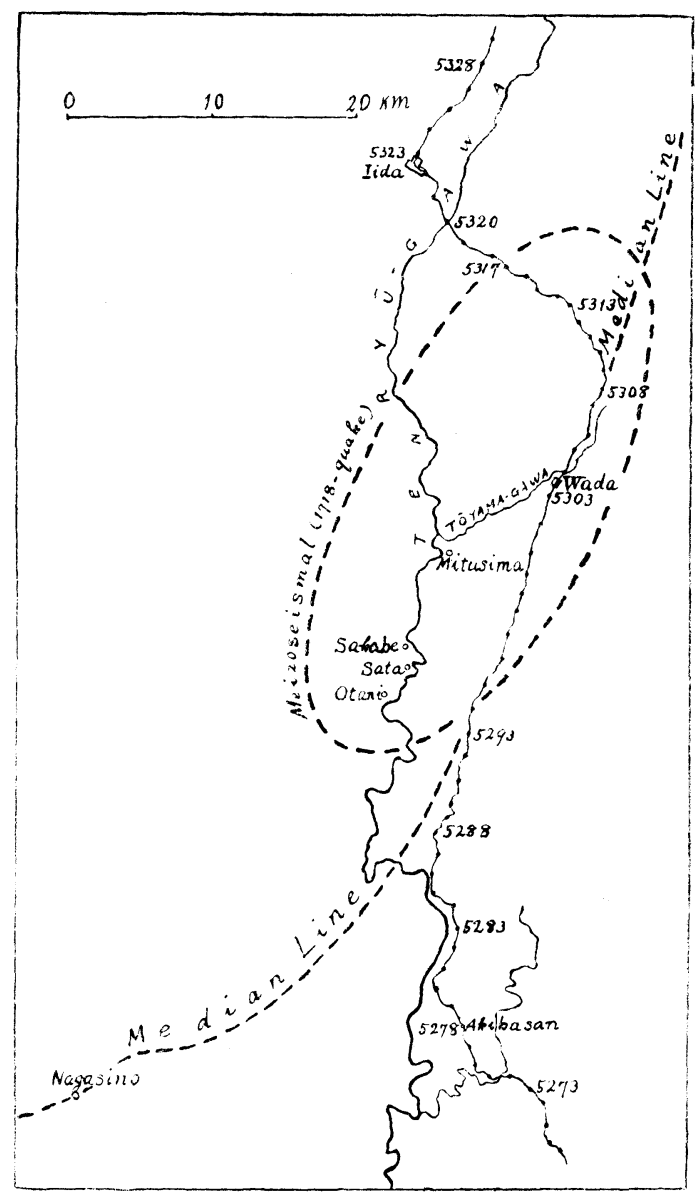

Fig. 2. Map showing the middle course of the Tenryu-gawa with the Median Line, the line of precise levels, and the meizoseismal due to the 1718 earthquake.

somewhere between the origins of the 1718 and 1944 earthquakes, say, in Tertiary tract lying north of Nagasino.

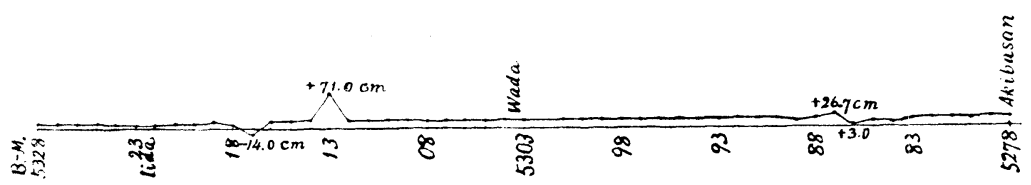

Fig. 3 .

12) About the north-eastern terminus of the Median Line. Here land deformation has been going on very actively since the time unknown, such that of bench-marks embedded there some 50 years ago, many were found to have undergone changes unfavorable for the 
measurement of pure vertical displacement ${ }^{1)}$. There were 9 such marks out of the total number of 35 complised in the section of level line between Oomati and Itoigawa. Although worked out imperfectly, it seems that land in the valley of the River Hime-kawa near the middle point of the section underwent during the 29 years ending in 1920 a relative vartical displacement of $13.3 \mathrm{~cm}$, whereas in the level line laid down on the coast was observed at the 4 bench-marks extent to the west of Itoigawa a conspicuous $\mathrm{N}$-shaped discontinuity with a throw of as much as $20.0 \mathrm{~cm}$ in the period of 30 years ending in 1920 , in addition to a chronic tilt of the Nisikubiki block as pointed out by the late Dr. N. Yamasaki.

In the district concerned originated in historic times a number of large earthquakes; namely, the destructive Oomati-gumi earthquake of 1714, the great Nadati earthquake of 1751, the Ettyu-Etigo earthquake of 863 , and so on.

It will thus be seen from the data so far given that land deformations occurring along the Median Line are extremely large as compared with those occurring in other parts of the country. In this connection it reminds us of the facts that whenever bench-mark had shown, as its chronic vertical displacement, an extraordinary large value, say a few decimetres for an interval of 30 or 40 years, it was generally regarded as a datum involving errors arisen from accident or some other unknown causes. In the present study, however, I have availed myself in assuming some of the changes in question as to be whether a harbinger or a rear of acute land deformation brought about by large earthquake, as I have dealt with in the cases of No. 10 or No. 11 in the above-mentioned examples. It would also be noteworthy that there may be even natural agency which can give rise to benchmark of an angular displacement against its upright position, as we have seen in those laid down in the Hime-kawa valley (see No. 12).

2) A. Imamura : Pnbl. Earthq. Inv. Comm., 25 (1928), Table IV. 